\title{
PLURALISME AGAMA DALAM AL-QUR'AN \\ Telaah Terhadap Tafsir Departemen Agama
}

\section{Oleh: Hadi Winarno, M.Pd}

\section{A. PENDAHULUAN}

Al-Qur'an adalah merupakan buku petunjuk yang diturunkan oleh Allah untuk manusia agar manusia bisa mengelola alam semesta ini dengan baik dan benar.Didalam Al-Qur'an terdapat aturan-aturan atau cara yang mengatur hubungan antar sesama manusia atau petunjuk yang harus dilakukan manusia untuk mengatur alam semesta ini agar tidak terjadi kerusakan artinya alam semesta ini boleh diambil manfaatnya tanpa menimbulkan suatu kerusakan.

Memang al-Qur'an tidak menjelaskan secara gamblang dan rinci mengenai setiap masalah yang akan dihadapi manusia, namun hanyamemberikan garis besarnya saja yang berisi rumusandan prinsip-prinsip yang dapat digunakan dandikembangkan dalam kehidupan baik secara pribadi dankehidupan bermasyarakat merumuskan prinsip-prinsip dasar yang dapat dijadikan pedoman dalam kehidupan manusia, termasuk dalam kehidupan berbangsa dan bernegara. Mungkin hikmahnya agar manusia menggunakan akal budi dan daya nalarnya seoptimal mungkin atau dalam terminologi fikih disebut berijtihad untuk menjelaskan pedoman yang sifatnya global tadi, kemudian menyesuaikannya dengan kondisi kehidupan mereka yang dinamis dan selalu berubah.Karena dalam prakteknya, semakin rinci dan detail sebuah aturan akan semakin sulit diimplementasikan dalam kehidupan yang dinamis dan berubah. Itulah sebabnya mengapa al-Qur'an dan ajaran Islam tidak ketinggalan zaman, dan selalu dapat menyesuaikan dengan situasi dan kondisi manusia yang berubah-ubah. Hal ini sesuai dengan kaidah al-Islâm shâlih li kulli zamân wa makân (Islam kompatibel dengan perkembangan zaman dan dimana saja). 
Inti ajaran Islam adalah tauhid, yaitu mengajarkan kepada manusia bahwa hanya ada satu pencipta, yaitu Allah swt. Selain Dia, semua hanyalah makhluk. Di antara ciptaan-Nya, manusia adalah makhluk yang paling sempurna (QS. Al-Isrâ/17: 70). ${ }^{1}$ Makhluk lain patut memberikan penghormatan kepada manusia.

Manusia adalah makhluk yang bermartabat dan harus dihormati tanpa membedakan ras, suku, bangsa, agama, warna kulit, bahasa, jenis kelamin, gender, dan berbagai ikatan primordial lainnya. Keragaman manusia adalah sunnatullah. Manusia diciptakan berbangsa-bangsa dan bersuku-suku agar mereka saling mengenal dan menghargai.

Pluralitas tidak hanya dari aspek kejadian manusia yang dulunya berawal dari yang tunggal, tetapi juga dalam aspek agama Samawi yang pada awalnya berawal dari satu agama-Tauhid—telah berubah menjadi realitas plural. Al-Qur'an telah memberikan prinsip-prinsip yang harus dipegang sebagai cara yang baik untuk mengatasi pluralitas tersebut. ${ }^{2}$

Nabi Muhammad saw. telah mencontohkan sebuah tatanan kehidupan yang tak berkonflik di tengah pluralitas agama dan suku. Dengan "Piagam Madinah" ${ }^{3}$ ternyata saat itu kedamaian mampu diwujudkan tanpa

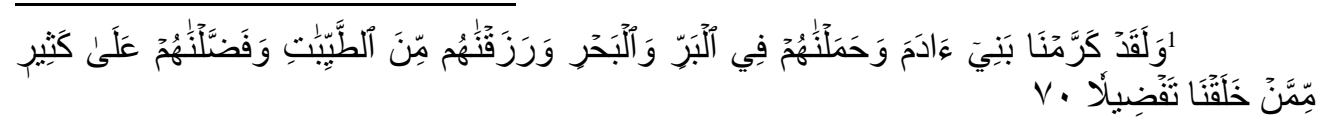
Dan Sesungguhnya telah kami muliakan anak-anak Adam, kami angkut mereka di daratan dan di lautan, kami beri mereka rezeki dari yang baik-baik dan kami lebihkan mereka dengan kelebihan yang sempurna atas kebanyakan makhluk yang telah kami ciptakan. (QS. Al-Isrâ'/17: 70)

2. QS. Al-Baqarah/2: 256; Al-Mâ'idah/5: 48, Yûnûs/10: 99

3. Dalam Piagam Madinah ini intinya menggarisbawahi lima hal pokok sebagai dasar bagi kehidupan bermasyarakat dan bernegara. Pertama, prinsip persaudaraan dalam Islam (ukhuwah Islamiyah), semua umat Islam dari berbagai latar belakang dan dari berbagai suku pada hakekatnya bersaudara. Kedua, prinsip saling menolong dan melindungi, penduduk Madinah yang terdiri dari beragam suku, agama, dan bahasa harus saling membantu dalam menghadapi lawan. Ketiga, prinsip melindungi yang teraniaya. Keempat, prinsip saling kontrol. Kelima, prinsip kebebasan beragama. Lihat Nurcholis Madjid, Islam dan Kebebasan Beragama, (PT. Gramedia Pustaka Utama bekerja sama dengan Yayasan Wakaf Paramadina, 1998), h. 195. 
perlu mengorbankan nyawa dan harta benda, namun mampu hidup berdampingan satu sama lain tanpa melihat perbedaan. Maka, patutlah kiranya kembali dapat diterapkan dalam konteks bermasyarakat sekarang.

Pluralitas/kemajemukan agama, perlu dipahami sebagai suatu realitas yang harus ditanggapi secara positif melalui dialog dan kerjasama untuk menemukan satu titik temu dan mencapai kalimah sawâ'. (QS. Âli 'Imrân/3:64). Pada dataran itu, sebagaimana dinyatakan Amin Abdullah setelah menyadari sifat truth claim (klaim kebenaran) yang terdapat dalam keyakinan para pemeluk agama yang berbeda-beda, ${ }^{4}$ kitab suci (al-Qur'an) ini mengajak seluruh penganut agama-agama non-Islam dan juga kepada penganut agama Islam untuk mencapai titik temu di luar aspek teologis yang memang sudah berbeda sejak awal.

Quraish Shihab mengakui bahwa dalam sejarah agama-agama telah terjadi pertikaian dalam pemeluk agama yang sama dan antar pemeluk agama yang berbeda. Tetapi pertikaian tersebut lebih disebabkan oleh kepentingan lain di luar agama. ${ }^{5}$ Manusia diberi kebebasan untuk menerima atau menolak petunjuk agama (QS. Yûnûs/10: 108; al-Isrâ'/17: 15; alKahfi/18: 29). Karena itu Tuhan menuntut ketulusan beragama dan tidak membenarkan paksaan dalam bentuk nyata maupun terselubung, besar atau kecil sekalipun (QS. Al-Baqarah/2: 256; Yûnûs/10: 99). Prinsip utama agama adalah kemaslahatan umat manusia. ${ }^{6}$ Dengan menggali ajaran-ajaran agama, meninggalkan fanatisme buta, dan berpijak pada kenyataan, jalan akan dapat dirumuskan.

4 Ayat-ayat al-Qur'an yang menginformasikan pemeluk masing-masing agama (utamanya tiga agama Samawi) mengklaim kebenaran akan agamanya adalah QS. AlBaqarah/2: 11, 120, 213 dan Âli 'Imrân/3: 85. Lebih lanjut lihat Amin Abdullah, Dinamika Islam Kultural; Pemetaan Atas Wacana Islam Kontemporer, (Bandung: Mizan, 2000), cet. I, h. 74.

${ }^{5}$ M. Quraish Shihab, Membumikan al-Qur'an, (Bandung: Mizan, 1996), cet. XII, h. 218 .

${ }^{6}$ Shihab, Membumikan al-Qur'an, h. 219. 
Universalitas al-Qur'an menunjukkan bahwa wahyu itu menerima pluralitas agama $^{7}$ (QS. Al-Baqarah/2: 62) sebagai suatu keniscayaan sehingga kaum muslimin harus menegosiasikan, mentransformasikan, dan menekankan kesatuan fundamental umat manusia sebagai sama-sama makhluk yang berasal dan diciptakan Tuhan. Al-Qur'an juga menegaskan bahwa keragaman manusia tidak terelakkan bagi suatu tradisi tertentu untuk menentukan kepercayaan umum, nilai, dan tradisi yang perlu bagi kehidupan masyarakat. ${ }^{8}$ Menjalin kedekatan dengan al-Qur'an menjadi sangat penting, karena umat Islam akan semakin toleran apabila memahami kandungan al-Qur'an dengan baik. Karena menurut Nurcholis Madjid yang menjadikan orang Islam tidak toleran adalah ketidaktahuannya tentang alQur'an. $^{9}$

Di Indonesia, Departemen Agama ${ }^{10}$ sebagai lembaga yang menaungi enam agama Islam, Kristen Protestan, Kristen Katolik, Hindu, Budha, dan

${ }^{7}$ Al-Qur'an memang tidak menyebut pluralitas agama secara langsung secara jelas. Al-Qur'an menyebutkan dengan "para penganut" atau "orang-orang" dalam menggambarkan adanya keragaman agama, misalnya dalam QS. Al-Baqarah/2: 62 disebutkan orang-orang beriman, orang-orang Yahudi, orang-orang Nasrani, dan Shâbi'în. Namun dalam berbagai kitab tafsir, khususnya dalam Al-Qur'an dan Tafsirnya Depag RI, dijelaskan yang dimaksud orang-orang yang beriman adalah orang-orang yang mengakui adanya Allah, para malaikatNya, kitab-kitab-Nya, para rasul-Nya, hari kiamat, dan qadha \& qadar. Sedangkan orangorang Yahudi adalah orang-orang yang menganut agama Yahudi. Orang-orang Nasrani adalah orang-orang yang menganut agama Nasrani. Dan Shabi'în adalah orang-orang yang mengetahui adanya Tuhan Yang Maha Esa, dan mempercayai adanya pengaruh bintangbintang.

Dari keterangan di atas, dapat dipahami meskipun secara eksplisit tidak menyebutkan agama secara langsung, namun secara implisit mengirformasikan adanya kemajemukan agama. Karena pemeluk agama tidak bisa dipisahkan dari agama yang dipeluknya. Alasan penulis memilih QS. Al-Baqarah/2: 62 dalam menjelaskan adanya pluralitas agama, akan dibahas pada sub bab Landasan Teori dalam Bab I ini.

${ }^{8}$ Sachedina, Beda Tapi Setara, h. 58.

${ }^{9}$ Nurcholis Madjid, Agama dan Dialog Antarperadaban, (Jakarta: Paramadina, 1996), h. 231

${ }^{10}$ Departemen Agama ini berdiri setelah Islam tidak bisa menjadi dasar negara Indonesia dan setelah kalimat "dengan kewajiban menjalankan syariat Islam bagi pemeluk- pemeluknya," dihapus dari Piagam Jakarta. Lembaga ini berdiri atas usulan - 72 -

Al Marhalah : Jurnal Pendidikan Islam. Volume. 11, No. 1 Mei 2017 
Pluralisme Agama dalam Al-Qur'an

Telaah Terhadap Tafsir Departemen Agama

Konghucu $^{11}$ memiliki peranan penting dalam upaya membangun dialog dan kerukunan antar umat beragama. Dengan berdirinya Departemen Agama sebenarnya berlaku kesetaraan antara semua agama, tidak ada minoritas maupun mayoritas agama, kesemuanya mempunyai hak-hak yang sama, yaitu kebebasan beragama sebagaimana tercantum dalam pasal 29 ayat 2 UUD 1945 sebagai salah satu kebebasan sipil pada tingkat warga.

Selain itu, Departemen Agama menerbitkan Al-Qur'an dan Tafsirnya yang telah mengalami beberapa revisi. Dan wacana tentang "pluralisme agama" di Indonesia telah marak sebelum revisi tafsir Departemen Agama Edisi Yang Disempurnakan (Th. 2004) dilakukan. Secara tidak langsung, pemaknaan kembali terhadap ayat-ayat al-Qur'an sesuai dengan kondisi sosial masyarakat juga perlu dilakukan oleh Departemen Agama. Penafsiran kembali inilah yang mendorong penulis untuk mengkaji dan meneliti lebih jauh tentang tafsir Departemen Agama Edisi Yang Disempurnakan, khususnya terhadap ayat-ayat pluralisme agama, di mana wacana tersebut marak di Indonesia sebelum edisi yang disempurnakan tersebut mulai dilakukan. Untuk itu, penulis

dua tokoh nasionalis sekuler, yaitu Syahrir dan Amir Syarifuddin, yang belakangan menjadi tokoh komunis. Karena mereka menyadari bahwa di kemudian hari pasti bisa timbul gejolak dari umat Islam untuk memasukkan delapan kata di atas dalam Undang-Undang Dasar 1945. Lihat makalah M. Dawam Rahardjo, Hari Depan Kebebasan Beragama di Indonesia, pada seminar "Masa Depan Kebebasan Beragama di Indonesia," di Universitas Paramadina pada 19 Juli 2006, bandingkan dengan Ahmad Sukardja, Piagam Madinah dan Undang-Undang Dasar 1945: Kajian Perbandingan Tentang Hidup Bersama dalam Masyarakat yang Majemuk, (Jakarta: UI Press, 1995), h. 152-154.

${ }^{11}$ Agama Konghucu diakui oleh pemerintah pada masa pemerintahan Presiden Abdurrahman Wahid (Gus Dur) dengan dikeluarkannya Kepres No. 6 Tahun 2000 yang mencabut Inpres No. 14 tahun 1967 tentang agama, kepercayaan, dan adat istiadat Cina. Meskipun Inpres tersebut tidak secara eksplisit mencabut pengakuan terhadap eksistensi agama Konghucu, namun dalam praktek di lapangan kesan pengingkaran terhadap agama Konghucu sangat dirasakan sehingga hak-hak sipil penganut agama Konghucu menjadi terabaikan, seperti masalah perkawinan di mana Kantor Catatan Sipil tidak mau mencatat, tidak memperoleh pendidikan agama Konghucu di sekolah, perayaan hari raya, dan sebagainya.dengan terbitnya Kepres No. 6 Tahun 2000, maka hak-hak sipil penganut agama Konghucu dipulihkan kembali. 
beri judul: "Pluralisme Agama dalam Al-Qur'an: Telaah Terhadap Tafsir Departemen Agama".

\section{B. PEMBAHASAN}

\section{Pluralisme}

Para pakar yang pernah meneliti tentang pluralisme agama, berbeda-beda dalam memilah dan mengutip ayat- ayat al-Qur'an berkenaan dengan wacana tersebut. Berikut ini akan penulis bandingkan pemilahan ayat-ayat al-Qur'an yang dilakukan oleh para peneliti wacana pluralisme agama tersebut, khususnya yang berkaitan dengan pengakuan al-Qur'an terhadap pluralitas agama, kebebasan beragama, dan toleransi beragama.

Abdul Aziz Sachedina misalnya, mengelompokkan ayat-ayat al-Qur'an yang berkaitan dengan wacana pluralisme agama. Menurutnya, ayat- ayat al-Qur'an yang termasuk dalam pembahasan pluralitas agama diantaranya QS. Al-Baqarah/2: 62 dan 213, al-Mâiidah/5: 48, dan alKâfirûn/109: 1-6. ${ }^{12}$ Sedangkan ayat-ayat al-Qur'an yang membahas tentang kebebasan beragama, diantaranya QS. Al-Baqarah/2: 256, Yûnûs/10: 99, dan Qâf/50: 45. ${ }^{13}$ Dan ayat-ayat al-Qur'an yang menjelaskan toleransi beragama, diantaranya QS. Al-Mâ'idah/5: 48 dan alAn'âm/6: $108 .^{14}$

Gamal al-Banna juga memilah ayat-ayat al-Qur'an yang terkait dengan wacana pluralisme agama sebagai berikut: 1) pluralitas agama: QS. Al- Baqarah/2: 62; ${ }^{15}$ 2) kebebasan beragama: QS. Al-Baqarah/2: 256,

\footnotetext{
${ }^{12}$ Sachedina, Beda Tapi Setara, h. 48-76.

${ }^{13}$ Sachedina, Beda Tapi Setara, h. 160 dan 169

${ }^{14}$ Sachedina, Beda Tapi Setara, h. 125 dan 167

${ }^{15} \mathrm{Gamal}$ al-Banna, al-Ta'addudiyyah fì al-Mujtama' al-Islâmiy, telah diterjemahkan ke dalam bahasa Indonesia oleh Taufik Damas dengan judul Doktrin Pluralisme dalam alQur'an, (Jakarta: Menara, 2006), h. 46. 
Pluralisme Agama dalam Al-Qur'an

Telaah Terhadap Tafsir Departemen Agama

Yûnûs/10: 99 \& 108, al-Isrâ'/17: 15, al-Kahfi/18: 29; ${ }^{16}$ 3) toleransi beragama: dalam pembahasan ini, secara eksplisit al-Banna tidak menjelaskannya, namun dia langsung membahas dan menjelaskan masalah "perbedaan" yang terjadi, baik seumat beragama maupun antarumat beragama diserahkan kepada Allah swt.-dari perspektif umat Islam. Al-Banna banyak mengutip ayat al-Qur'an yang mengandung kata ikhtalafa (berselisih) dengan berbagai derivasinya, diantaranya: QS. AlBaqarah/2: 113, Âli 'Imrân/3: 55, al- Mâ'idah/5: 48, al-An‘âm/6: 164, Yûnûs/10: 19 \& 93, al-Nahl/16: 124, al-Syûrâ/42: 10, al-Sajdah/32: 25, dan al-Zumar/39: $46 .^{17}$

Fathimah Usman memilah ayat-ayat al-Qur'an yang termasuk dalam pembahasan pluralitas agama. Menurutnya, Ayat-ayat al-Qur'an yang ia kutip ini adalah pengakuan al-Qur'an terhadap para pemeluk agamaagama yang berarti diakuinya agama-agama mereka. Diantara ayat-ayat tersebut adalah QS. Al-Baqarah/2: 62 dan al-An'âm/6: $108 .^{18}$ Fathimah hanya mengutip satu ayat al-Qur'an yang membicarakan tentang kebebasan beragama, yaitu QS. Al-Baqarah/2: $256 .{ }^{19}$ Sedangkan toleransi agama tidak termasuk dalam pembahasan penelitiannya.

J. Suyuthi Pulungan dalam bukunya "Prinsip prinsip Pemerintahan dalam Piagam Madinah Ditinjau dari Pandangan alQur'an" mengelompokkan ayat-ayat al-Qur'an yang membicarakan tentang kebebasan beragama, yaitu QS. Al-Baqarah/2: 256, Yûnûs/10: 99, Yûsuf/12:103, dan al-Kâfirûn/109: $6 .^{20}$ Dalam hal prinsip hubungan

\footnotetext{
${ }^{16}$ Al-Banna, Doktrin Pluralisme, h. 19-20.

${ }^{17}$ Al-Banna, Doktrin Pluralisme, h. 72-73.

${ }^{18}$ Fathimah Usman, Wahdat al-Adyan: Dialog Pluralisme Agama, (Yogyakarta: LkiS, 2002), h. 71-71.

${ }^{19}$ Fathimah, Wahdat al-Adyan, (Yogyakarta: LkiS, 2002), h. 70

${ }^{20}$ J. Suyuthi Pulungan, Prinsip-prinsip Pemerintahan dalam Piagam Madinah Ditinjau dari Pandangan al-Qur'an, (Jakarta: PT. RajaGrafindo Persada, 1996), cet. ke-2, h. 166-168 dan 313.
} 
antarpemeluk agama, Pulungan mengelompokkan QS. Al-Mâ'idah/5: 5, al'Ankabût/29: 46, dan al-Mumtahanah/60: 8-9. ${ }^{21}$ Namun, Pulungan tidak membahas masalah pluralitas/kemajemukan agama dalam bukunya ini.

Hendar Riyadi misalnya, memilah ayat-ayat al-Qur'an sesuai dengan pesan/isi yang dikandung oleh ayat yang dikutipnya. Riyadi mengelompokkan QS. Al-Baqarah/2: 148 dan al-Mâ'idah/5: 48 sebagai penegasan terhadap pluralitas atau kemajemukan agama. Sedangkan QS. al-Baqarah/2: 62, Riyadi masukkan dalam pembahasan jaminan keselamatan bagi komunitas agama-agama yang termasuk dalam Ahl al-Kitâb (Yahudi, Nashrani, Shabiî̀n), bahkan Riyadi mengutip QS. alHajj/22: 40 untuk menjelaskan pengakuan atau penerimaan atas spiritualitas agama-agama, bukan hanya dimaksudkan untuk menjaga integritas masyarakat multiagama. Dalam hal kebebasan beragama, Riyadi hanya mengutip QS. Al-Baqarah/2: 256 dalam penjelasannya. Sedangkan masalah toleransi beragama, Riyadi mengelompokkan QS. Al-Mâidah/5: 48 dan 2, al- An'am/6: 108, al-Nisâ'/4: 86, dan alMumtahanah/60: 8. Ayat-ayat tersebut, Riyadi kelompokkan dalam pembahasan toleransi, khususnya berbicara tentang kompetisi untuk saling berbuat baik dan melakukan kerja sama/pertemanan dalam rangka kemanusiaan dan masih dalam koridor hubungan antaragama.

Quraish Shihab memilah ayat-ayat al-Qur'an yang termasuk dalam pembahasan tentang kebebasan beragama, yaitu QS. Al-Baqarah/2: 256, Yûnûs/10: 99, al-Kâfirûn/109: 6, al-Mumtahanah/60: 8, dan alKahfi/18: 29. Shihab mengelompokkan QS. Al-Mâ'idah/5: 48, al-Syûrâ/42: 15, al- Mumtahanah/60: 8, al-Baqarah/2: 272 dalam pembahasan tentang toleransi beragama. Namun, Shihab tidak membahas masalah

\footnotetext{
${ }^{21}$ Pulungan, Prinsip-prinsip, h. 172-173 dan 313-314. -76 -
} 
pluralitas/kemajemukan agama sehingga beliau tidak melakukan pemilahan ayat-ayat al-Qur'an yang terkait dengan pembahasan tersebut.

Pemilahan ayat-ayat al-Qur'an terhadap masalah pluralisme agama yang dilakukan oleh para peneliti wacana ini sebelumnya, berbedabeda dalam jumlah pengutipan ayat. Namun, ayat-ayat al-Qur'an yang dikutip dalam satu pembahasan, ada yang memiliki kesamaan. Misalnya pembahasan pluralisme agama tentang pengakuan pluralitas agama, Abd Aziz Sachedina, Gamal al-Banna, Fathimah Usman, dan Riyadi, semuanya mengutip QS. al-Baqarah/2: 62. Meskipun, Riyadi mengelompokkan ayat tersebut ke dalam bahasan keselamatan bagi komunitas agama-agama yang termasuk dalam Ahl al-Kitâb (Yahudi, Nashrani, Shabiînn), secara tidak langsung juga mengakui adanya pluralitas agama. Sedangkan Suyuthi J. Pulungan dan Quraish Shihab tidak mengutip QS. al-Baqarah/2: 62, karena mereka tidak membahas masalah pluralitas agama.

Kesamaan kutipan ayat-ayat al-Qur'an juga terdapat dalam pembahasan kebebasan beragama, yaitu: QS. al-Baqarah/2: 256 dan Yûnûs/10: 99. Sedangkan tentang toleransi beragama, kesamaan ayat al- Qur'an yang dikutip adalah QS. Al-Mâ'idah/5: 48.

Dari penelusuran pemilahan ayat-ayat al-Qur'an yang terkait dengan wacana pluralisme agama, khususnya tentang pluralitas agama, kebebasan beragama, dan toleransi beragama, pada hakekatnya terdapat kesamaan ayat al-Qur'an yang dikutip oleh semua peneliti yang penulis sebutkan sebelumnya, meskipun hanya satu ayat al-Qur'an.

Berdasarkan keterangan di atas, dapat dilakukan penggabungan dan penambahan dalam pengelompokan ayat-ayat al-Qur'an yang telah dilakukan oleh para peneliti sebelumnya terkait dengan wacana pluralisme agama, khususnya masalah pluralitas agama, kebebasan beragama, dan 
toleransi beragama. Penggabungan di sini, dimaksudkan bukan memasukkan pemilahan seluruh ayat-ayat al-Qur'an yang telah dilakukan oleh para peneliti sebelumnya yang penulis sebutkan di atas, melainkan memilih dari ayat-ayat al-Qur'an yang telah dipilah tersebut, sesuai dengan pesan atau isi dasar dari masing-masing ayat Sedangkan penambahan ayat-ayat al-Qur'an, dimaksudkan menambah ayatayat al-Qur'an yang menurut penulis lebih sesuai daripada ayat al-Qur'an yang telah para peneliti kutip sebelumnya. Dan penambahan ayat-ayat alQur'an ini juga dengan memperhatikan pesan atau isi dasar yang dikandung oleh ayat al-Qur'an yang dikutip.

Dan dengan pertimbangan lain, satu ayat al-Qur'an terkadang memiliki lebih dari satu bahasan. Karena memiliki lebih dari satu bahasan, kadangkala penulis memasukkan ayat al-Qur'an yang sama dalam dua pembahasan yang berbeda. Seperti QS. Al-Mâ'idah/5: 48 selain menjelaskan tentang pengakuan adanya keragaman umat/ komunitas agama dengan diberikan syariah dan jalan terangnya masing masing, juga menjelaskan tentang anjuran berkompetisi berbuat baik dan segala keputusan terhadap apa yang diperselisihkan oleh semua umat,-terkait dengan siapa yang benar dan salah, atau siapa yang masuk surga dan neraka-akan diselesaikan oleh Allah swt.

Atas dasar kerangka pemikiran inilah, kita dapat melakukan pemilahan terhadap ayat-ayat al-Qur'an yang akan dibahas sesuai dengan pokok bahasan tentang pluralisme agama, khususnya masalah pluralitas agama, kebebasan beragama, dan toleransi beragama. Kita pun dapat mengutip ayat- ayat al-Qur'an yang terkait dengan masalah yang di bahas sebagai pendukung dan penguat penjelasan terhadap masalah pembahasan. Terkait dengan pluralitas agama, ayat-ayat al-Qur'an yang 
dapat dibahas adalah QS. Al-Baqarah/2: 62; Al-Baqarah/2: 148; AlMâ'idah/5: 48 \& 69; dan al-Hajj/22: 17.

Tentang kebebasan beragama, ayat-ayat al-Qur'an yang dapat dibahas adalah QS. Al-Baqarah/2: 256; Yûnûs/10: 99 \& 108; al-Isrâ'/17: 15; dan al- Kahfi/18: 29. Sedangkan tentang toleransi beragama, ayatayat al-Qur'an yang dapat dibahas adalah QS. Al-Maidah/5:48 dan alAn'am/6:108.

\section{Kajian Penelitian Data}

Bila kita ingin meneliti pluralisme dalam qur'an, maka data-data yang berkaitan dengan literatur yang digunakan dibagi menjadi dua, yaitu data primer dan data sekunder. Data primer yang diperlukan dalam penelitian ini diperoleh dari buku yang dikaji atau buku- buku yang relevan langsung dengan tema pokok yang dikaji. Buku-buku yang dimaksud adalah "al-Qur'an dan Tafsirnya" karya Departemen Agama RI tahun 1983/1984, 1985/1986, 1989/1990, dan 2004 (edisi yang disempurnakan), "al-Qur'an dan Tafsirnya".

Adapun data sekunder, penulis peroleh dari beberapa referensi yang terkait dengan wacana pluralisme agama, baik yang berbahasa Arab, Inggris, maupun Indonesia untuk mengkaji dan membandingkan dengan penafsiran Departemen Agama tentang pluralisme agama. Referensi yang dimaksud antara lain The Holy Qur'an oleh Yusuf Ali, Tafsir al-Mishbah karya M. Quraish Shihab, Islam dan Pluralitas oleh Muhammad Imarah, Beda Tapi Setara oleh Abdul Aziz Sachedina, Islam dan Doktrin Peradaban oleh Nurcholish Madjid, Islam, Pluralisme \& Toleransi Keagamaan oleh M. Fathi Osman, dan beberapa kitab-kitab tafsir yang berbahasa Arab, diantaranya karya Ibn Katsîr, al- Thabarî, al-Qurthubî, alZamakhsyarî, al-Alûsî, al-Qâsimiy, dan Wahbah Zuhailî. Di samping 
itu, beberapa tulisan/makalah yang terkait dengan objek kajian ini turut dijadikan rujukan. Seperti Menimbang Tafsir Depag RI oleh Adang Kuswaya, Menuju Kebebasan Beragama di Indonesia oleh Siti Musdah Mulia, Hari Depan Kebebasan Beragama di Indonesia oleh Dawam Rahardjo, dan lain-lain.

\section{Kajian Pembahasan}

Secara deskriptif dengan tujuan memberikan gambaran tentang suatu masyarakat atau kelompok orang tertentu atau gambaran tentang suatu gejala atau hubungan antara dua gejala atau lebih.33 Di sini, penulis akan menggambarkan dan mengurai penafsiran Departemen Agama yang tertuang dalam al-Qur'an dan Tafsirnya terhadap ayat-ayat pluralisme agama. Adapun pluralisme agama di sini mencakup pembahasan tentang pluralitas agama, kebebasan beragama, dan toleransi beragama.

Analitis sebagai upaya eksplorasi dan klarifikasi mengenai fenomena pemhaman, pemaknaan, interpretasi al-Qur'an, dan mengukuhkan pengetahuan tentang berbagai eksperimen tersebut. Dan analisis isi (content analysis) dilakukan untuk menganalisis penafsiran al-Qur'an dan Tafsirnya Departemen Agama seputar ayat-ayat pluralisme agama.

\section{KESIMPULAN}

Pluralitas tidak hanya dari aspek kejadian manusia yang dulunya berawal dari yang tunggal, tetapi juga dalam aspek agama Samawi yang pada awalnya berawal dari satu agama-Tauhid-telah berubah menjadi realitas plural. Al-Qur'an telah memberikan prinsip-prinsip yang harus dipegang sebagai cara yang baik untuk mengatasi pluralitas tersebut. -80 -

Al Marhalah : Jurnal Pendidikan Islam. Volume. 11, No. 1 Mei 2017 


\section{DAFTAR PUSTAKA}

Abdullah, Amin, Dinamika Islam Kultural; Pemetaan Atas Wacana Islam Kontemporer, (Bandung: Mizan, 2000), cet. I

al-Banna, Gamal, al-Ta'addudiyyah fì al-Mujtama' al-Islâmiy, telah diterjemahkan ke dalam bahasa Indonesia oleh Taufik Damas dengan judul Doktrin Pluralisme dalam al-Qur'an, (Jakarta: Menara, 2006)

Departemen Agama RI, al-Qur'an dan Tafsirnya, tahun 1983/1984, 1985/1986, 1989/1990, dan 2004 (edisi yang disempurnakan)

Fathimah, Wahdat al-Adyan, (Yogyakarta: LkiS, 2002)

Madjid, Nurcholis, Agama dan Dialog Antarperadaban, (Jakarta: Paramadina, 1996)

Madjid, Nurcholis, Islam dan Kebebasan Beragama, (PT. Gramedia Pustaka Utama bekerja sama dengan Yayasan Wakaf Paramadina, 1998)

Quraish Shihab, M, Membumikan al-Qur'an, (Bandung: Mizan, 1996), cet. XII

Sukardja, Ahmad, Piagam Madinah dan Undang-Undang Dasar 1945: Kajian Perbandingan Tentang Hidup Bersama dalam Masyarakat yang Majemuk, (Jakarta: UI Press, 1995)

Suyuthi Pulungan, J, Prinsip-prinsip Pemerintahan dalam Piagam Madinah Ditinjau dari Pandangan al-Qur'an, (Jakarta: PT. RajaGrafindo Persada, 1996), cet. ke-2

Usman, Fathimah, Wahdat al-Adyan: Dialog Pluralisme Agama, (Yogyakarta: LkiS, 2002) 